\title{
Managing Risks Model for Creative Developing in Islamic banks
}

\author{
Abdullah Ibrahim Nazal \\ Zarqa University \\ Fuad Suleiman Al- Fasfus \\ Zarqa University
}

This study investigates managing risk model for creative developing projects in Islamic banks to success it's sharing in developing. The paper finds that there is a negative impact and positive impact for applying creative developing projects in Islamic banks, therefore it needs to be managed by standards depending on impacts of total quality insurance to cover needs, understand relationship between managing risks ways and expect cost. The paper suggests managing risk model by rule the creative developing contracts types with standards in order to control its impact in Islamic banks positively.

\section{INTRODUCTION}

There are ideas to support creating developing project concentrating on poor people. They are the highest amount in country. It is way to give depression solution and reduce stress on government. Bryden, et. at (2013) discuss government innovation for sustainable developing. They found that it must be more directed at the needs of poor people.

Islamic banks have to share in developing economic. It has Islamic investing tools, financing tools and saving tools. Its customers think it is way to apply Sharia rules in order to protect them from tricks, ignorance, and forbidden tools as dealing with interest rate. It has to prove its developing as way to solve depression in economic by courage creative developing projects. Islamic banks develop investing tools as Sukuk based on selling by Morabaha services, sharing by Mousharakah services, leasing, working by Istisnah services. There is need now to use these developing services in financing creative developing projects as way to help country developing success. Islamic bank ways to meet creative developing contract flexibility as follow:

1. Adjusted operation steps, procedures, and conditions to reduce creating developing contracts risk as adding insurance conditions to protect capital, and reduce step of storing goods to reduce creating developing cost of store by own commercial company.

2. Selling projects as investing Sukuk contracts in order to get liquidity and get more profit, also it is way to transfer risk which will success creating developing finance

3. Collect investing projects by different types in one portfolio to manage risk as using many types of services in creative developing projects

4. Merge services as merging saving service and investing service in one operation to courage creating developing operations. 
Managing contract affect on managing structure positively. Human resources in Islamic banks have standards to success creative developing projects as follow:

1. Accepted by law.

2. Contract will give net profit.

3. Reduce risks.

4. Give disclosure in financial tables.

5. Give benefit for government, customer, supporter, creditor, employees.

6. Give future value.

7. Manage risk practically

8. Support Islamic bank shares price in financial market.

The problem of creative developing projects success is possibility needs long term to success but it will give high profit than other projects, also improves or develops civilization locally, and it will be way to deal with international market to increase profit because of globalization.

"There is strong statistical relationship between product development and economic development. This often presented as evidence that product development causes economic development by promoting investment and making allocation of resources more efficient" (Pedro and Erwan, 2010:p804). Developing is important to transfer companies' lifecycle from regression stage to growth stage. As developing affect on companies, it affects on economic sectors lifecycle which can be led by government. Some governments as in United Arab Emirates try to apply creative developing strategy in order to transfer its growth to other strategy. It applied total quality insurance strategy before and success. The standard to success is to covering currently needs and future needs. It can make citizen life luxury and easy to solve problems with suitable costs. This step will be supported by multinational companies as experts. "Increasing in international competition produce effect that reduces domestic profits and income" (Impullitti, 2010: p1152) this step needs supporting and must have the success factors. One of these factors is balancing managing risk.

Financing risk managing is advance financing managing. It means to avoid loss or reduce loss or transfer loss by financing or investing tools. It becomes important as result to complexity factors affect on balance sheet and income statement results. Many factors and many changes increase with technology tools which give fast dealing with out limit time. Traditional managing may face loss and accept the loss to get in bad case but risk managing can transfer loss or reduce this loss to change loss affection. Financing and investing are contracts have duties and rights in law. Managing risk tools have negative affect as transfer risk to customer, government, creditors and other competition companies therefore it affects negatively on government developing planning, investing and saving. By negative effect, it becomes block to success creative step to destroy creative efforts even there is support from government.

\section{The Problem}

There is need to find suitable model to mange creative developing risk in Islamic banks in order to share in developing. The problem increases as result to fast unclear developing of financial tools and negative misunderstanding affection of transfer risk managing to other companies, speculators and governments. It causes loss of investing and savings. Third world economics in many countries get in depression as result to negative affection of financial tools and investing tools. It loses its effort and time to transfer its economics from producing up total quality insurance to reach creative economic. It cannot depend on equilibrium between demand and supply in its economic to change depression case as in developed countries because it not reach the self sufficient in economic. This case costs loss of developing effort, time, investing and savings. Government tried to bush liquidity to help economic and make demand to restructure the investing and success local companies sales while other countries courage international companies to help economic regardless of negative affection on local companies in spite of loosing local developing sharer.

The problem questions are:

1. What is the developing as creative strategy?

2. What is the relationship between total quality insurance and creative developing? 
3. What is the relationship between managing risks ways and creative developing?

4. What is the cost of applying creative developing?

5. What are the needs to build risks managing model for creative developing?

\section{The Importance}

This search shows factors affect on creative developing projects risks to build risks managing model for creative developed financing and investing in Islamic banks. It helps to understand the risks managing impacts and directing developing tools to success by reduce costs and time to reach creative developing step in real economic and success Islamic bank effort in developing countries.

\section{The Objectives}

This search aims to find negative risk managing affection also to find risk managing success factors for companies, speculations and governments. It suggests balancing risks managing model for creative developed financing and investing. It is way to avoid bad affection of using managing risks by developed tools in creative developing case.

\section{Searches Related to Study}

Some studies explained that developing tools affect on companies and government as (Pedro and Erwan, 2010) showed that financial development causes economic development by promoting investment and making allocation of resources more efficient. (David, George, 2011) concentrated on international attention asks for Public- Private Partnerships as away to develop country and transfer industry. Thomas, (2011) explained that, the standard of success tools types is to finance and invest up to suitable time with suitable cost so there must be financing tool, investment tools and saving tools to make money staying. There are many studies show the creative developing. Some studies discuss the developing of managing restructure as apply Islamic rules to organize the company, ex: Elsiefy, (2013) concentrated on the differences between Islamic banks and Traditional banks before, during and after the financial crises in 2008 by financial ratios. There were different in liquidity, credit, risks, profitability and solvency therefore affection of crises becomes different. Other studies discuss developing standards to meet needs of disclosure, ex: Lucouw, (2013) tried to solve problem of discloser. He showed the important of financial statements which must be done up to suggest model. The model recalculates certain financial statement figures to what it could have been. This can make comparing between current statements and expect statement. There are studies discuss developing tools affection as studied of T. M and Afsal, (2008) that explained affection of future contracts and options contract on the cash market in India by general index called S\&P CNX Nifty Index. There was no affect of changing introduction of derivatives as developed tools in market. Nazal, (2006) aims to study Islamic rules affection on developing tools in Islamic banks in Jordan, he found there is need to make developing model to meet needs but this need marketing mix up to Islamic rules take care of environment changing and banks strong points and weakness points. Recommendation was to collect all Islamic rules that affect on developing tools and arrange these rules to direct and control operation practically as suggestion model to explain difference between Islamic organizations than traditional organizations.

\section{The study model is as follow:}

Suggest of managing risks model:

- Standard of creative strategy

- Standard of total quality insurance

- Standards of managing risk choices

- Standards of accept Cost of applying creative developing

- Standards to apply Islamic rules on projects contract to avoid interest rate dealing, ignorance, and harm.

$\longrightarrow$\begin{tabular}{l|}
\hline $\begin{array}{l}\text { Islamic banks Creative } \\
\text { developed success: } \\
\text { - Meet poor people needs } \\
\text { - Meet developing service } \\
\text { - Solve problem of deficient }\end{array}$ \\
\hline
\end{tabular}




\section{Creative is Strategy Developing}

Developing products is creative strategy. It has advantages, as increasing quality to be similar as competitor products or solving customer problems which had with competitor products or giving unique benefit to customer or establishing standards better than competitor (Rebecca and Kwaku, 2011:106). Developing is way to face needs changing which affects on product sales. Sales may get in growth as result to covering customer real needs or it get in fail because of disagree between product benefits and customer real needs. This case will obligate organization to change product benefit to be agreed with customers needs or it has to be canceled to avoid loosing of sales cost. Ex: First world customers accept new computer programs so the old computer programs will lose sales. Changing of needs has affected by civilizations level, income, traditional and way of customer managing personal saving, investment and financing. Customers are types. Every type may show different needs in same country. Customer could be citizen or company or government or foreign customer. Products have been developed to meet the following needs:

1. Needs to get goods as food.

2. Needs to get services as health services.

3. Needs to get suitable investment as shares.

4. Needs to get suitable financing as loan.

5. Needs to get suitable managing risk flexibility to meet changes of customer risks as insurance against fire.

Developing may be caused to get developed investing tools or financing tools or standards or way of managing or model to understanding affect of factors but it had limits or negative affection and need to discuss as Capital Assets Pricing Model which depends on interest of center bank bonds, market risk and market return regardless affection of tax, commissions and other risks which not systemic risk also it imagine that individual cannot affect the price of stock by his buying and selling action (Edwin and Martin, 1995). Tools have ways to be developed as follow:

1. Find new tools as leasing ended by owning contract to avoid tax as result to consider lease installments expenses to increase cost and give way to grantee owning in future.

2. Improve tools up to contract conditions by add new conditions and reduce conditions as delay buying cash in future.

3. Collect many tools to be one tool without merge to show cost and profit of each tool as give investor bank current service with currency changing service and buying his liability up to orders.

4. Collect many tools to be one tool with merge as new tool .

5. Accept changing contract to other contract as changing lease contract to be selling contract.

6. Add condition to get welfare as add condition to delay giving price for owning goods in currently time to be suitable to its liquidity when it gets cash flow which help to avoid getting loan and its costs also company will get time to sell goods and buy in obligated future time.

There is bad affection to developing as result to quick developing as result to technology and computer programs. Ability of companies direct developing to avoid its problem regardless of bad affection on dealers as in table 1: 
TABLE 1

BAD AFFECTION OF COMPANIES DEVELOPING TOOLS ON DEALERS AIMS

\begin{tabular}{|c|c|c|}
\hline Dealers & Way of developing tool & Affection \\
\hline $\begin{array}{l}\text { (Liabilities Payable) } \\
\text { as result to get } \\
\text { company loan from } \\
\text { creditors }\end{array}$ & $\begin{array}{l}\text { Increase getting goods } \\
\text { currently with delay } \\
\text { buying cash or get cash } \\
\text { loans by other creditors to } \\
\text { buy the loan in the } \\
\text { current time or use bonds } \\
\text { to finance buying loan in } \\
\text { time. }\end{array}$ & $\begin{array}{l}\text { Increase liabilities over standards and may get in } \\
\text { default to get in clear without cover creditors } \\
\text { rights. This case increases because of weak } \\
\text { grantee. Shareholders limit their responsibility just } \\
\text { up to their shares in this company regardless of } \\
\text { size of creditors' loss. This case increase losing of } \\
\text { government pushing liquidity in economic to } \\
\text { make growth. It will loss effort of creative } \\
\text { developing planning }\end{array}$ \\
\hline $\begin{array}{l}\text { (Assets note } \\
\text { receivable) as result } \\
\text { to company gives } \\
\text { loan to customers }\end{array}$ & $\begin{array}{l}\text { Sell loan by discount to } \\
\text { transfer default risk to } \\
\text { other creditor }\end{array}$ & $\begin{array}{l}\text { Will increase ignorance as transfer dealing to the } \\
\text { loan buyer. Loan buyer may apply rules to buy } \\
\text { with his power to get loan without delay to get loan } \\
\text { grantee or to clear defaulter from market. This case } \\
\text { will cause reducing of investing and producing as } \\
\text { result to other creditor ruling. }\end{array}$ \\
\hline Shareholders & $\begin{array}{l}\text { Sell shares directly in } \\
\text { financial markets or sell } \\
\text { shares in projects by } \\
\text { investing contract }\end{array}$ & $\begin{array}{l}\text { Will increase sharers and there bad affection by } \\
\text { speculation up to rumors or up to controlling } \\
\text { managing as the big owner who direct managing to } \\
\text { achieve his welfare or transfer possibility of loss to } \\
\text { other sharers. }\end{array}$ \\
\hline Customers & $\begin{array}{l}\text { Buy long term products } \\
\text { with maintenance with } \\
\text { expect quality with } \\
\text { changing cost and expect } \\
\text { to reduce cost by time }\end{array}$ & $\begin{array}{l}\text { Selling customer contracts with commission to } \\
\text { other producer or sell maintenance procedures to } \\
\text { other company will give customer ignorance to get } \\
\text { his covering needs and the changing cost will } \\
\text { direct customer to loss as possible to loss quality } \\
\text { from the new buyer or increasing price after } \\
\text { customer sign the contract. }\end{array}$ \\
\hline Government & $\begin{array}{l}\text { Expect to get tax and } \\
\text { cover citizen needs with } \\
\text { low cost than import }\end{array}$ & $\begin{array}{l}\text { Company can transfer human resources as experts } \\
\text { to from the country (A) to other country (B) also it } \\
\text { can use capital and land to decrease cost of } \\
\text { producing by producing in the country (B) and } \\
\text { export from the country (B) to meet country (A) } \\
\text { citizen needs without reducing cost. it can sell in } \\
\text { other country and avoid buying income tax to the } \\
\text { country (A) }\end{array}$ \\
\hline
\end{tabular}

Resource: by searchers

\section{Relationship between Creative Developing and Total Quality Insurance}

There is relationship between applying success managing by total quality insurance and creative developing because it tries to cover customers' current needs and future needs. This will follow developing needs up to developing civilization. It builds the ability up to corporation between all managers and workers to find customer needs and cover it up to improving and developing goods with suitable price. Step by step, the quality of goods also will be developed to get in creative developing case. Practically, companies which own total quality insurance certification have three types. It may apply total quality insurance standards to reach creative to help in reaching creative developing country. Some companies have the total quality insurance certificate as promotion to their products and increase price but without real quality as expect. It increases price just up to promotion which reduces customer saving 
and reduces value added for sharing in creative developing. Some companies have the total quality insurance certification but it needs time to be apple to share in creative as result to training which needs support from shareholders and government to cover the high cost for first steps. It needs grantee to prove its ability to be sharer in creative developing in future or supporting will be loss in future. Government supporting companies in many countries by reduce tax, get grants and get loan with low interest. This supporting must be linked to company success in reaching creative by steps which are:

Step 1: to produce products with quality up to local needs

Step 2: to produce products with international quality to international needs as apply ISO standards.

Step 3: to produce products up to changing needs by apply Total quality insurance management.

Step 4: to produce developed products as applying creative ideas practically to make dreams facts.

Supporting by government will be loss in general budget expenses when company uses support to make short return in speculation and cover loan by other loan. These ways will not share in creative developing. The way of covering loan by other loan will delay current problem but not solving it. The problem will be increase in future as result to increase interest as cost on loan without real return on other hand speculation will affect on demand and supply as false index to show increasing of demand or decreasing up to expecting not up to real needs therefore equilibrium point will be false and not suitable to rule economic pricing fairly. Expectation has costs. It increases loss when it causes wrong decision. Products must cover customer needs as applying internet buying tool. Needs are shown as in table 2:

TABLE 2

\section{CUSTOMER EVALUATE BUYING SERVICES BY BANK INTERNET CARD}

\begin{tabular}{|c|c|c|}
\hline $\begin{array}{l}\text { Customer needs to complete procedures to get } \\
\text { bank internet card }\end{array}$ & $\begin{array}{l}\text { Customer needs to } \\
\text { apply procedures to } \\
\text { buy with bank internet } \\
\text { card }\end{array}$ & $\begin{array}{l}\text { Customer needs after } \\
\text { buying with bank } \\
\text { internet card }\end{array}$ \\
\hline Has Current account & $\begin{array}{l}\text { Time to follow } \\
\text { information of the bank } \\
\text { card and password }\end{array}$ & $\begin{array}{l}\text { To get product or } \\
\text { services that had be } \\
\text { bought }\end{array}$ \\
\hline Has return every month & $\begin{array}{l}\text { Linking must be } \\
\text { accepted for seller and } \\
\text { suitable to buy }\end{array}$ & \multirow{8}{*}{$\begin{array}{l}\text { To buy commission } \\
\text { to seller organizers } \\
\text { or international } \\
\text { organizer }\end{array}$} \\
\hline Customer can limit monthly buying to $1000 \$$ & $\begin{array}{l}\text { Bank not responsible on } \\
\text { security of customer } \\
\text { buying }\end{array}$ & \\
\hline No fees to get the card for first time & \multirow{6}{*}{$\begin{array}{l}\text { If it information and } \\
\text { secrets be stolen } \\
\text { customer has to cancel } \\
\text { the card to stop losing } \\
\text { savings or he will lose it. }\end{array}$} & \\
\hline No commission from customer on buying & & \\
\hline $\begin{array}{l}\text { Can buy from internet services or products which } \\
\text { accepted by Islamic rules }\end{array}$ & & \\
\hline $\begin{array}{l}\text { Any buying fees will be deducted from the account } \\
\text { after (19) day from each month }\end{array}$ & & \\
\hline $\begin{array}{l}\text { If customer need to cancel the card services he has } \\
\text { to buy } 15 \$\end{array}$ & & \\
\hline $\begin{array}{l}\text { If the is no cash in customer account to deduct } \\
\text { buying costs customer will buy } 15 \$ \text { to get back the } \\
\text { services but there is no interest rate added. }\end{array}$ & & \\
\hline
\end{tabular}

Resource: by searchers

Covering customer needs is standard to success in total quality insurance management. Eric and Lorin, (2000) explained that internet services show different way of pricing. Internet reduces cost of transfer and increase customer surplus which courage customer to make addition investment in internet 
bank service. Lo Liang .et. at (2010) found that electronic services quality affected by changing role of the banking system and dynamic financial market. They are responsible on customer loyalty. Muslim and Zaidi, (2008) has result that electronic bank services quality must meet customer needs to get satisfaction.

\section{Relationship between Managing Risks Choices and Creative Developing}

There are many ways to managing risks. The ways produce strength point to protect company from loss or less loss but it will cause the loss to other company, customers and government as result to transfer this loss to them. Creative developing needs sharing to success between companies, customers and government but when they transfer loss on each other there will not be sharing. It will lead to conflict between then to blame each other on failed case. Managing risks must give suitable result to all sharers in creative developing. Speculation with managing risks investing or financing tools to get unusual return will cause short term contracts while creative developing need long term contract to success practically. Managing risks can be directed to develop investing tools and financing tools to cover needs of creative developing. Developing has advantages, as increasing quality to be similar as competitor products or solving consumer problems which had with competitor products or giving unique benefit to consumer or establishing standards better than competitor or reduce cost (Rebecca and Kwaku, 2011). Managing risks has two sides as follow:

First: to reduce loss, transfer loss, reduce costs and increase returns. It is strength point to company which will satisfied shareholder as result to get good return and protect investing. It will satisfy government as result to get suitable tax and satisfied customers because of covering their needs with suitable prices.

Second: to transfer loss to cause problems to government, customers and other sharers. It may cause reduce of expect return to reduce tax and shareholders returns. It may increase customer costs. Unlimited managing risk will cause ignorance to understand evaluation of company which affect on its sector index and may reduce sector developing to reduce economic growth. This case will reduce country credit classification degree because of increasing risks.

Derivative affection increase as result to finance amount which it is more than real economic producing finance amount. Some dealers do not looking for real product or service which affect on producing amounts therefore they accept the settlement of the contract to buy instead of harm to the other contracting compensation as result to speculation. See figure 1:

\section{FIGURE 1 \\ DERIVATIVES CAUSE FALSE DEMAND OR SUPPLY ON PRODUCING}

\begin{tabular}{llll}
\hline & $\mathbf{A}^{\prime}$ & $\mathbf{A} 2$ & Products price
\end{tabular}

\section{Resource: by searchers}

A: price comes by real demand and supply.

A2: price comes by false demand and supply, to increases price.

A1: price comes by false demand to reduce price.

The international swaps and derivatives association research notes no (2) in 2009 that: "New survey shows that $94 \%$ of the world's largest corporations report - Using derivatives to manage business and macroeconomic risks" (David, Anatoli and Julia, 2009, p217). Practically, derivatives are promising to cover demand. Problem comes as result to make change of equilibrium point between demand and supply because of false demand cause false supply to producer. Derivatives speculation become gambling tool not hedge risk tool. 


\section{Cost of Applying Creative Developing}

Applying creative developing will affect on costs, it may increase the cost currently and in future as result to unsuccessful applying or it will increase cost currently with reducing cost in future. Some countries reduce cost currently and in future. This comes as result to creative developing demands available and good planning with experts in developing. Some countries do not apply quality standards in managing or producing therefore it needs to build demands of success and it will be costly. Cost of demands and way of applying affected by the planning to get developed product, marketing developed product, maintenance developed product and producing developed product. There are factors affect on cost and make flexibility to account the cost. It is different from country to other. See table 3:

\section{TABLE 3}

\section{FACTORS AFFECT ON CREATIVE DEVELOPING SUCCESS}

\section{The factors: \\ Sharing in producing or maintenance or training or marketing}

1-Commission as Marketer, ex: country apply creative developing from other country in order to get tax or commission as import any products

2-Return to producer and must increase than cost, ex: country may be sharer to get part of return and finance its general budget or return must get by foreign producer.

3-Return for maintenance, ex: it may be sharing by country as sharer or transfer to foreign producer. 4-Return for trainer to show way of using creative developing or transfer way of maintenance or way of producing, ex: it may be sharing by country as sharer or transfer to foreign producer

Reason to apply creative developing

1-To solve problem in future

2-To solve current problem

3-To make life more easier as result to developing aims

4-To reduce

5-To get in globalization classifications

Way of transfer creative developing

1- Get creative developing from other country and apply it by get training on using creative developing.

2- Get creative developing from other country and apply it by get training on using creative developing and maintenance.

3-Get creative developing from other country and apply it by get training on using creative developing, maintenance and sharing in developing.

4-To get creative developing by local resources.

5-Get creative developing from other country as marketer

Available demands to success

1-Experts human resource from local resource or foreign resource or sharing between them

2-Capital from local resource or foreign resource or sharing between them

3-Cover real needs

4-Law to show rights and duties and control applying creative developing.

5-Possibility to develop creative developing products when it gets in loss stage.

Harm and Trickery

1-Controlling country by creative developing country with monopolization which may control secrets and increasing costs in directly case.

2-Controlling speculations, ex: selling creative developing projects shares as investing to transfer its capital and risk to leave the country 
What are the suitable choices to solve applying creative developing problems

1-Find local solution

2-Find foreign solution

3- Find sharing way between local and foreign solution to solve problem

4- No solution

Resource: by searchers

\section{CONCLUSION}

There is negative impact and positive impact for applying creative developing projects in Islamic bank therefore it need to be managed by standards. Creative developing is the other step after understanding total quality insurance because it will give idea about ways to cover needs. There is need to understand relationship between Managing risks ways and creative developing also there is need to understand expect cost of applying creative developing. Tables 1,2 and 3 are showing the factors that impact success as suggestion model. It helps to increase economic growth or transfer from regression case growth. Managing risk apply developing tools for financing and investing. It has two sides which are negative side to transfer loss to others and the positive side as developing tools to give market suitable ways to growth and face different needs. Creative developing need costs which it is different up to size of sharing between government and companies in order to meet real current needs and future needs therefore there is need to build balancing risks managing model for creative developing to face negative affection of sharing types and negative affection of managing risk.

\section{RECOMMENDATION}

Searcher suggest managing risk model in Islamic banks by rule the creative developing contracts types with standards in order to control managing risk affection as transfer risk or reduce loss by accept risk partly or avoid loss by find other way. Applying rules of developing in Islamic banks must have two types:

1. Fixed rules for every time and place in current cases and developed cases, it is standard to give fair out come to company, customer and government as protect environment from pollution to avoid harm also fixed rules to obligate contract developing from cheating or producing forbidden products as drugs. It includes contract with obligated Condition to be done and anther Forbidden Conditions to be avoided to get rights and done duties which rule balance of country, customer and organization welfares.

2. Flexibility rules changed up to change in time and place to cover changing in needs. It includes contract with conditions which are not obligated but better to be done and anther conditions which are not forbidden but better to be avoided. It rules way of dealing and promotion. Also it includes accepted condition up to negotiation to get better changes.

The rules become standards to apply creative developing. Standards are way to direct restructure managing organization also restructure financial and investment. Restructuring is way gives flexibility to managing risks. Standards may apply by government or companies or company leader. It is way to limit independence factors affection. It directs managing producing, developing and relationship therefore elements of managing as planning, organizing and controlling have been affected with standards. Any company faces its problem by managing restructure or financial and investing restructure or together. It is important to understand restructure negatively affection and positively affection and try to avoid or reduce negative affection to get in balancing case with greeting positive affection.

Managing risks affect on returns by restructuring and developing tools. This affection could be negatively on objectives of government, shareholder, customers, creditors, other companies. This affection will cause loss, ex: derivatives are developed tools. It is promising contract to deal in future. Amount of dealing give future increase demand but currently there is no increase demand. 
There is need to find creative developing demands to success therefore the suggest model must take care of the sharing in creative developing. Sharing will be between government, citizens and companies as strategy. There will be fixed steps to limit time and step success achieving standards also it needs to restructure economic sectors to be suitable to accept changing and apply creative developing, see figure 2 :

\section{FIGURE 2}

\section{STANDARDS OF CREATIVE DEVELOPING PROJECTS CONTRACT

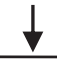

Standards as flexibility rule to meet different needs and changing of needs for companies, customers and government
Standards as fixed rule to all developed contracts to protect companies, customers and government from cheating or harm

Standards up to contract type to decide duties and rights by law which are:

1- Major contract: Sell, Lease, Loan, Share, Work and Grantee.

2- Major contract divisions as developed contracts, ex: share for long term and short term or direct and indirect sharing. It causes decreasing sharing, permanent sharing, short sharing, changing sharing by effort to be sharing with capital, and sharing by Blocks

Standards to use the suitable contract in suitable time and place up to balancing between negatives results and positive results

Standards to reduce negative affection by transfer risk or reduce risk partly or avoid risk as limit bonds selling to avoid transfer loan default to buyer and to protect economic

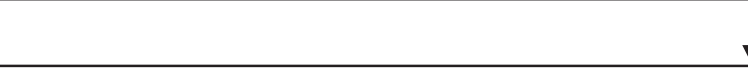

Standards to reach customer, company and government aims practically

Directing companies to cover real needs and avoid or reduce the bad negative affect of managing risks to share in creative developing

\begin{tabular}{|l|l|}
\hline $\begin{array}{l}\text { Avoid unacceptable ignorance, cheating, } \\
\text { prohibited contracts and harm }\end{array}$ & $\begin{array}{l}\text { Avoid bad affect on culture, } \\
\text { speculation, direct investing, } \\
\text { savings and relationship }\end{array}$ \\
\hline $\begin{array}{l}\text { Increase good affect to support transferring from total managing quality as standards to reach } \\
\text { creative developing in indirect investing and direct investing }\end{array}$ \\
\hline
\end{tabular}

Resource: by searchers 


\section{REFERENCES}

Amin. M and Isa. Z,(2008), an examination of the relationship between services quality perception and customer satisfaction, International Journal of Islamic and Middle Eastern finance and management, Malaysia, 1( 3), p191 and 209. http://www.emeraldinsight.com.

Bryden. J,et.at(2013), Governing innovation for sustainable development : designing creative institutions, Norwegian agricultural economics research institute, Norwegian, p1.

file://C:/Users/1952/Downloads/N201305Hele.pdf

Clemons. E and Hitt. L, (2000), the internet and the future of financial services: Transparency, Differential Pricing and disintermediation, The Wharton financial institutes Center, p29-30. http://fic.wharton.upenn.edu/fic/papers/00/0035.pdf

David. H and George. G, (2011), The Substance of accounting for Public-Private Partnerships, Financial Accountability and Management, 27(1), p217.

Elton. E and Gruber. M, (1995), Modern portfolio theory and investment analysis, John Wiley and sons, Inc. New York, USA, p294.

Elsiefy. E, (2013), Comparative analysis of Qatar Islamic banks performance versus conventional banks before, during and after the financial crisis, International journal of business and commerce, 3 (3), p11. http://www.ijbenet.com

Impullitti. G, (2010), International Competition and U.S. R\&D Subside: A Quantitative welfare Analysis, , International Economic Review, Economic Department of University of Pennsylvania and the Osaka University Institute of Social and Economic Research Association, 51(4), p1152.

Kheng. L, et .at,(2010), The impact of service quality on customer loyalty: A study of Bank in Penang, Malaysia, International Journal of Marketing studies, Canadian center of science and education,.2(2), p57, http://www.ccsenet.org.

Lucouw. P, (2013), Interpreting Financial Statements, journal of finance and investment analysis, UK, 2(1), pp 69 - 71. http://www.scienpress.com

Mengle. D, Kuprianov. A and Pachos. J, (2009), derivatives usage survey: OTC derivatives in Russia, the international swaps and derivatives association research notes, New York, USA, no.2, p1, www.isda.org

Nazal. A, (2006), The Effect of Sharia Controls on Development of Banking Services- A Theoretical Empirical Study, Ph.D. Dissertation, College of Banking and Financial Sciences, Amman, Jordan.

Pedro S. A and Erwan. Q, (2010), Limited Enforcement, Financial Intermediation, and Economic development: A Quantitative Assessment, International Economic Review, Economic Department of University of Pennsylvania and the Osaka University Institute of Social and Economic Research Association, USA, 51(3), p80

Rabecca. J.S and Kwaku. A.G, (2011), Product development Team stability and new Product advantage: the Role of Decision Marketing Processes, Journal of Marketing, American Marketing Association, U.S.A, 75(1), p 106.

T. Mallikarjunappa and Afsal E. M., (2008), The Impact of Derivatives on Stock Market Volatility: A study of the Nifty Index, Asian Academy of Management Journal of Accounting and Finance, India, 4 (2), Pp43 and 63. http://web.usm.my

Thomas H.W, Zieseme, (2011), Saving finance emigration and worker remittances serve to make staying rather than migrating possible, international Economic Journal, UK, 25(3), p373. 